\title{
A SCALE DESIGN OF PERSONAL COMPETENCES ASSOCIATED WITH VIRTUES IN UNIVERSITY STUDENTS: AN APPROXIMATION STUDY
}

\author{
Paula Crespi ${ }^{1 *}$, Jesús Rodríguez ${ }^{2}$, Jorge López ${ }^{3}$, Belén Obispo-Díaz ${ }^{4}$ \\ ${ }^{1}$ Prof. Dr., Universidad Francisco de Vitoria, SPAIN, p.crespi.prof@ufv.es \\ ${ }^{2}$ Prof., Universidad Francisco de Vitoria, SPAIN, jesus.rodriguez@ufv.es \\ ${ }^{3}$ Prof. Dr., Universidad Francisco de Vitoria, SPAIN, jorge.lopezgonzalez@ufv.es \\ ${ }^{4}$ Prof., Universidad Francisco de Vitoria, SPAIN, b.obispo@ufv.es \\ ${ }^{*}$ Corresponding author
}

\begin{abstract}
Integral formation is undoubtedly one of the great pretensions of higher education in the 21st century. By integral education we understand that which is directed at the whole person, and which aims at the harmonious development of all their dimensions and faculties. This education, which places the student at the centre, making them the protagonist of his learning, is designed so that each student discovers and carries out their own life project. A relevant contribution to integral education is the development of cardinal virtues (prudence, justice, fortitude and temperance) through competency-based learning. This study presents the design of a measurement instrument on personal competences, based on cardinal virtues and whose purpose is to measure the degree of development of the undergraduate's integral formation. Accordingly, each item of the questionnaire measures the self-perception of development of some of the transversal competences linked to cardinal virtues. The competences measured are critical thinking, decision-making, resilience, proactivity, self-improvement, emotional management, servant leadership and teamwork. The questionnaire was subjected to expert validation. The main results confirm that the questionnaire reaches an acceptable level of interjudge agreement, although minor changes suggested by experts are introduced. Thus, it can be concluded that this study presents a relevant questionnaire to measure the self-perception of the development of some competences associated with cardinal virtues that contributes to the integral formation of undergraduates. In this sense, this questionnaire may be useful for university community since it allows to test among students whether the curricula are acceptable in terms of integral formation.
\end{abstract}

Keywords: Integral formation, cardinal virtues, competences, questionnaire, validation, higher education.

\section{INTRODUCTION}

University has been and continues to be a critical element in the evolution and improvement of society to the extent that it is consistent with its commitment to the search for truth and goodness. University, from its earliest origins, has been configured as a community of truth seekers (Pérez-Díaz, 2010). The search for 
truth, is the universal task of every corporation of teachers and undergraduates, regardless of the path that is traced to reach it and of the discussion on the conception of truth (Esteban \& Román, 2016). A search for the truth about man, reality, and the ultimate meaning of life, which has no greater pretension than setting students on their own path of fulfilment, through the relentless pursuit of their own vocations revealed in their life projects and able to improve society they are part of (Crespí, 2019). Accordingly, there is an association between the search for truth and the integral formation of undergraduates.

In the same way, we agree with García-Ramos (2017) identifying that the mission of University consists in improving the world and society through transforming and ennobling the spirit of undergraduates. Thus, the purpose of university lies in the cultivation of spirit, and the formation of students (not only academics instruction, or the simple accumulation of data and scientific erudition).

Five main objectives related to the mission of university are identified (García-Ramos, 2017): search for truth (aimed at promoting a broad look to discover it), integral formation (aimed at forming all dimensions of man), synthesis of knowledge (oppositely to fragmentation of knowledge or hyper-specialization), service to man (any profession or science must be focused on the good of mankind) and service to society (the ultimate purpose of university is the improvement of society).

Although these objectives are important and, some are connected to others, this research focuses on integral formation.

Integral formation, as a process, is understood as that which makes possible the complete development of man, leading their life to a well-formed conscience that allows them to make free, responsible and consistent decisions (García-Ramos, 1991). Decisions motivated by a desire of good that contributes to communion, understood as the purpose of human being. For García Hoz $(1970,1997)$ integral formation, as the result of an educational process, takes the form of moral, religious, intellectual, physical, aesthetic and any other type of formation aimed at developing the dimensions and faculties of the person. According to Domínguez Prieto (2011), dimensions refer to three different aspects (corporal, psychic and spiritual) in which the person can project themself. Faculties are understood as three interrelated capacities for action: intelligence, will and affectivity. Good, as value, is the reason that stimulates will and "triggers" action.

Integral formation is a comprehensive and complex construct. Attempting to evaluate integral formation, whether as a process or as an outcome, is disproportionate. For this reason, we have chosen to identify those formative outcomes of integral formation that are particularly relevant and can be considered the "core" of integral formation. Following Greco-Latin tradition, we understand that the four classic cardinal virtues (prudence, justice, fortitude, and temperance) are the axis of integral formation. Excellence of human action (which leads to communion) passes through the exercise of cardinal virtues, and the development of them perfects, in the sense of putting into action, the faculties in order to personal and community good. Virtues refer to good firm and stable qualities of the person, that prepare them to know the truth by perfecting his intelligence and his will, and also to perform, freely and joyfully, excellent actions in order to reach his human and supernatural completeness (Trigo, 2010).

More generally, virtues refer to the habitual disposition to do well. On the other hand, cardinal virtues are essential to social order and personal relationships, as they look for common good. Cardinal virtues lead human behaviour towards their own development, integration, and fulfilment, allowing the creation of a better society.

Virtues acquired through personal effort, freely performing good actions with constancy, are human virtues, natural or acquired. Some of them (intellectual virtues) perfect especially the intelligence in the knowledge of truth. Others (moral virtues) perfect will and affections for the love of good (Trigo, 2010).

This study presents the design of a questionnaire on personal competences linked to cardinal virtues. The purpose of this questionnaire is to contribute to the measurement of integral formation of undergraduates based on certain personal competences.

As we will see below, there is a remarkable proximity between the concepts of virtue and competence. Hence, we have opted for an educational model based on competences as the basis for evaluating integral formation in cardinal virtues. The European Higher Education Area (EHEA), through the Tuning Project (González \& Wagenaar, 2008) emphasizes the development of competences, especially generic competences (also known as "soft skills"). These generic competences (capacities or dispositions to act) are the result of an educational process that enables an excellent performance. Competences, according to Tuning project, can be of different types: theoretical knowledge (ability to know and understand), procedural knowledge (know-how) but also know how to be. Competences understood in this way are very close to the classical concept of intellectual, technical, and moral virtues. 
As mentioned above, virtue refers to the habitual disposition to do good, which allows men to carry out a work with excellence and to fulfil themselves as human beings. It is not enough to have values (moral principles that guide our behaviour towards good) but they must be personified, lived, and revealed in human behaviour, so it can be said that somebody "possess" a virtue or is virtuous. The virtuous man performs good complying with their most inner inclinations (Pieper, 2017). Behaviour follows being.

On the other hand, we understand competence as the dynamic set of knowledge (know), skills or abilities (know-how), attitudes and values (know how to be) that, internalized and personified in actions, behaviours or ways of doing, put man on the path to maturity, excellence, fulfilment and happiness (Crespí, 2019).

Thus, both virtue and competence refer to habitual behaviour oriented towards good; which develops, perfects, integrates and fulfils the person, allowing, the creation of a better society. Certainly, some definitions of competence avoid mentioning intentionality or purpose as an element of it. In this way, an ethical neutrality would be sought in its conceptualization, which does not seem possible nor convenient. Anyway, it is true that, as in virtues, there are competences of different types: some perfect the work that is carried out (technical) and others also perfect the person who works (moral or ethical). Aristotle's Ethics (1985) allows to make a distinction between ethical competences (whose behave implies a praxis that involves a "know how to be") and technical competences (whose behave implies a techné or "know-how").

\subsection{Questionnaire design}

\subsubsection{Design of the dimensions and indicators of the questionnaire}

First, we proceeded to review similar research to our study. We tried to find proposals that link competencies to the four cardinal virtues. In this sense, we found the Leadership Virtues Questionnaire (LVQ). It defines "an ethical leader as one who adheres to the four cardinal virtues of prudence, fortitude, temperance, and justice" (Riggio et al., 2010, p. 235). This questionnaire served as our inspiration, although our study aimed to represent the various virtues mentioned in different critical competencies. The Transversal Personal Competencies Questionnaire (CCPT) was also consulted, which gathers the main competencies aimed at the integral formation of the university students (Crespí \& García-Ramos, 2021).

In this sense, assuming these concepts of virtue and competence, we decided to research and select, from among the generic competences, those common to different subjects, degrees or professions, usually required for life (Crespí \& García-Ramos, 2021). Those competences that best represented the four cardinal virtues and thus could best express the core of integral formation.

Consequently, for each of the four cardinal virtues that constitute the dimensions of our integral formation model, eight competences (two for each cardinal virtue) were deployed as indicators. A summary definition of the cardinal virtues and competences selected is shown below.

- Prudence: The capacity for critical judgment. Prudence consists in knowing and indicating what should be done to achieve a purpose or a good properly. It is both an intellectual and moral virtue, which characterises and directs other virtues. Moreover, prudence is not only the first among the others, but it usually "dominates" every moral virtue (Pieper, 2017).

There are two skills that help to perform prudential acts:

Deliberation: It consists in considering, by oneself or with the help of others, the pros and cons of an action, whether it is good or not, in order to a purpose previously apprehended. The opposite is precipitation.

Good judgment: consists in deciding properly about the right way to achieve the known purpose. The opposite is inflexibility or rigidity of judgment.

In this sense, we select the competences of:

- Critical thinking: It refers to the ability to recognize, analyze, value, order and interpret what surrounds us; trying to figure out the truth and reaching a justified idea, rejecting possible biases.

- Decision-making: It refers to the ability to choose among several options the one that is considered the best and most valuable. Thus, decision making involves a whole process of choosing one plan of action over another (Muñoz et al., 2011).

- Fortitude: The capacity to resist and undertake, that is the capacity to overcome fears and act.

Thomas Aquinas, following Aristotle, gives relevance to resistance understood as perseverance in the face of adversity (Pieper, 2017). From psychology, this virtue is very close to resilience. 
On the other hand, "to undertake" refers to not being paralyzed by fear and act towards good; what it is understood by proactivity.

Therefore, we have selected the following competences:

- Resilience: It refers to the ability to face adversity and coming out stronger. Consequently, resilience implies, on the one hand, to resist harm (carrying out appropriate and positive adaptive behaviours), on the other hand, to recover from harm constructively (Grotberg, 1995; Vanistendael, 2003).

- Proactivity: It refers to the ability to undertake actions that allow us to achieve our goals, dreams, our life project. It is the ability to take charge and responsibility for life, making decisions and assuming consequences (Covey, 2009; Frankl, 1979). Being proactive implies taking responsibility for making things happen, deciding at each moment what we want to do and how we are going to do it. The opposite is called reactivity, adopting an attitude in which the person is carried away by circumstances, attributing to them the cause of the consequences (Manual del Formador HCP, 2018).

- Temperance: A moral virtue that consists of moderating sensible desires and using created goods with balance.

The selected competences linked to this virtue are the following:

- Personal development: It refers to the continuous capacity for learning and improvement; which allows to achieve goals and acquire new habits, managing a better version (personal/professional) of oneself (Manual del Formador HCP, 2018).

- Emotional management: It refers to the ability to recognize, understand and properly manage emotions. Emotional management implies the recognition of own and others' emotions, as well as a right adaptation of them to the current situation, in order to guide actions (Goleman, 1995; Salovey \& Mayer, 1990).

- Justice: It consists in giving to the other what belongs to them according to their right or dignity. It is the main of the moral virtues and, in a certain way, the best result of them. Justice implies a relationship with the other (iustitia est ad alterum). It is the capacity to live in truth with one's neighbour (Pieper, 2017). It is a relational virtue inherent to human will, hence it has as purpose to give to the other what is "theirs". Justice is concretized in actions that have a social transcendence. According to Thomas Aquinas, some of the virtues related to justice are:

Equity: Giving impartially what is due.

Piety: Attending to the needs of one's homeland, parents and, generally, the others). It is related to service.

Considering the above, we selected the competences of:

- Leadership: It refers to the ability to accompany and guide others towards good, so they can reach their best version and their goals. It implies putting oneself at their service, knowing, accepting and helping others to improve as a person and, if it is the case, as a team.

- Teamwork: It refers to the ability to work cooperatively with different and complementary people, which whom a common goal or mission is shared. It favours understanding and comprehension; as well as an adequate management of possible conflicts.

\subsubsection{Questionnaire items}

The Competences and Virtues Questionnaire (CVQ) is shown below. Table 1 shows for each virtue, its two associated competences, as well as six items (three for each competency), for a total of 24 items. 
Table 1. Content of the items of the Competences and Virtues Questionnaire (CVQ)

\begin{tabular}{|c|c|c|}
\hline VIRTUE & COMPETENCE & ITEM \\
\hline \multirow{2}{*}{ Prudence } & Critical thinking & $\begin{array}{l}\text { 1.- I question the ideas (my own or others'). } \\
\text { 2.- I compare my ideas with reality. } \\
\text { 3.- I change my ideas if I find reasons to do so. }\end{array}$ \\
\hline & Decision making & $\begin{array}{l}\text { 1.- When I have to make an important decision, I identify different alternatives. } \\
\text { 2.- I ask for advice from people of reference before making important decisions. } \\
\text { 3.- I make decisions considering the possible consequences of my actions. }\end{array}$ \\
\hline \multirow{2}{*}{ Fortitude } & Resilience & $\begin{array}{l}\text { 1.- I face adversity with a positive attitude. } \\
\text { 2.- I easily overcome problems or adverse situations. } \\
\text { 3.- After an adverse or unfavorable situation I come out stronger. }\end{array}$ \\
\hline & Proactivity & $\begin{array}{l}\text { 1.- I assume responsibility for the consequences of my actions. } \\
\text { 2.- I take the initiative to achieve my goals. } \\
\text { 3.- When I encounter obstacles, I implement solutions. }\end{array}$ \\
\hline \multirow{2}{*}{ Temperance } & Personal growth & $\begin{array}{l}\text { 1.- I identify aspects to improve in my life. } \\
\text { 2.- I set goals that challenge me. } \\
\text { 3.- I am consistent in achieving my goals. }\end{array}$ \\
\hline & $\begin{array}{l}\text { Emotional } \\
\text { management }\end{array}$ & $\begin{array}{l}\text { 1.- I know how to name my emotions. } \\
\text { 2.- I understand my feelings and emotions. } \\
\text { 3.- I manage my emotions, adapting them to the situation of the moment. }\end{array}$ \\
\hline \multirow{2}{*}{ Justice } & Leadership & $\begin{array}{l}\text { 1.- I get involved with my colleagues so that everyone contributes with the best of } \\
\text { themselves. } \\
\text { 2.- I help others when they need it, regardless of my affinity with them. } \\
\text { 3.- I guide others in a reasonable way to achieve their goals. }\end{array}$ \\
\hline & Teamwork & $\begin{array}{l}\text { 1.- When I work as part of a team, I favor a climate of listening among all members. } \\
\text { 2.- I comply with the tasks established in the work team. } \\
\text { 3.- When I work in a team, I collaborate with my teammates trying to improve the } \\
\text { work done. }\end{array}$ \\
\hline
\end{tabular}

Note: own elaboration.

\section{METHOD}

\subsection{Validation of the questionnaire by a panel of experts}

Validity refers to accuracy with which we can measure the construct we want to study in a questionnaire. A first approach for validating questionnaires is expert judgment (Escobar \& Cuervo, 2008; García-Ramos, 1986).

In this sense, once the CVQ had been designed, it was submitted for expert judgment to obtain evidence of content validity. In other words, it was checked whether CVQ can measure the eight competences associated with the four cardinal virtues in the context of the integral formation of undergraduates.

Regarding the number of experts, there is no unanimity on the appropriate number that should form the panel. In our case, 6 experts on competences, virtues, integral formation and research methodology were convened. First, experts received an informative e-mail explaining the objective of the study, the purpose of the measurement instrument and the request for evaluation. CVQ was available through the virtual platform Jotform.

After that, each expert was asked to rate, for each item the following criteria on a scale of 1 (the criterion is not reached) to 6 (the criterion is satisfactorily reached):

○ Clarity $(\mathrm{C})$ of the item in terms of writing and comprehension.

o Relevance $(R)$ of the item to the competency and virtue to be measured.

- Appropriateness $(A)$ of the item to the competency and virtue to be measured.

\section{RESULTS}

Quantitative and qualitative results of the validation process by the panel of experts are shown below.

\subsection{Quantitative results}

Prudence shows a mean of 5.49 out of 6 (Table 2). On the other hand, Critical thinking and Decision-making show also high mean values (5.26 and 5.72 respectively). Regarding the average for each item (assessing the criteria of clarity, relevance, and appropriateness) are in all cases higher than 5. However, "low" values 
are observed in Critical thinking competency, especially to the clarity criterion (means between 4.0 and 5.3 ).

Table 2. Prudence evaluation

\begin{tabular}{|c|c|c|c|c|c|c|c|c|c|c|c|c|c|c|c|c|c|c|}
\hline & \multicolumn{18}{|c|}{ PRUDENCE } \\
\hline & \multicolumn{9}{|c|}{ CRITICAL THINKING } & \multicolumn{9}{|c|}{ DECISION-MAKING } \\
\hline & \multicolumn{3}{|c|}{ ITEM 1} & \multicolumn{3}{|c|}{ ITEM 2} & \multicolumn{3}{|c|}{ ITEM 3} & \multicolumn{3}{|c|}{ ITEM 1} & \multicolumn{3}{|c|}{ ITEM 2} & \multicolumn{3}{|c|}{ ITEM 3} \\
\hline & $\mathrm{C}$ & $\mathrm{R}$ & $A$ & $\mathrm{C}$ & $\mathrm{R}$ & $A$ & $\mathrm{C}$ & $\mathrm{R}$ & $A$ & $\mathrm{C}$ & $\mathrm{R}$ & $A$ & $\mathrm{C}$ & $\mathrm{R}$ & $A$ & $\mathrm{C}$ & $\mathrm{R}$ & $A$ \\
\hline EXPERT 1 & 6 & 6 & 6 & 5 & 5 & 6 & 6 & 4 & 4 & 5 & 5 & 5 & 6 & 5 & 5 & 6 & 6 & 6 \\
\hline EXPERT 2 & 6 & 6 & 6 & 6 & 6 & 6 & 6 & 6 & 6 & 6 & 6 & 6 & 6 & 5 & 6 & 6 & 6 & 6 \\
\hline EXPERT 3 & 4 & 6 & 5 & 6 & 6 & 5 & 5 & 4 & 5 & 6 & 6 & 6 & 6 & 4 & 4 & 6 & 6 & 6 \\
\hline EXPERT 4 & 4 & 6 & 6 & 6 & 6 & 6 & 6 & 6 & 6 & 6 & 6 & 6 & 6 & 6 & 6 & 6 & 6 & 6 \\
\hline EXPERT 5 & 1 & 5 & 5 & 2 & 4 & 4 & 6 & 6 & 6 & 6 & 6 & 6 & 6 & 6 & 6 & 1 & 6 & 6 \\
\hline EXPERT 6 & 3 & 6 & 6 & 3 & 6 & 6 & 3 & 6 & 6 & 6 & 6 & 6 & 6 & 6 & 6 & 6 & 6 & 6 \\
\hline X CRITERIA & 4.0 & 5.8 & 5.7 & 4.7 & 5.5 & 5.5 & 5.3 & 5.3 & 5.5 & 5.8 & 5.8 & 5.8 & 6.0 & 5.3 & 5.5 & 5.2 & 6.0 & 6.0 \\
\hline X ITEM & \multicolumn{3}{|c|}{5.17} & \multicolumn{3}{|c|}{5.22} & \multicolumn{3}{|c|}{5.39} & \multicolumn{3}{|c|}{5.83} & \multicolumn{3}{|c|}{5.61} & \multicolumn{3}{|c|}{5.72} \\
\hline X COMPETENCE & \multicolumn{9}{|c|}{5.26} & \multicolumn{9}{|c|}{5.72} \\
\hline X VIRTUE & \multicolumn{18}{|c|}{5.49} \\
\hline
\end{tabular}

Regarding Fortitude (Table 3), it shows a mean of 5.50 out of 6 . Moreover, Resilience and Proactivity show high mean values (5.28 for the resilience and 5.72 for proactivity). Each item reach, in all cases, a mean higher than 5 in clarity, relevance and appropriateness. However, it is observed again "lower" values for clarity criterion in Resilience competency, especially in items 1 and 3 (4.7).

Table 3. Fortitude evaluation

\begin{tabular}{|c|c|c|c|c|c|c|c|c|c|c|c|c|c|c|c|c|c|c|}
\hline & \multicolumn{18}{|c|}{ FORTITUDE } \\
\hline & \multicolumn{9}{|c|}{ RESILIENCE } & \multicolumn{9}{|c|}{ PROACTIVITY } \\
\hline & \multicolumn{3}{|c|}{ ITEM 1} & \multicolumn{3}{|c|}{ ITEM 2} & \multicolumn{3}{|c|}{ ITEM 3} & \multicolumn{3}{|c|}{ ITEM 1} & \multicolumn{3}{|c|}{ ITEM 2} & \multicolumn{3}{|c|}{ ITEM 3} \\
\hline & $\mathrm{C}$ & $\mathrm{R}$ & $A$ & C & $\mathrm{R}$ & $A$ & $\mathrm{C}$ & $\mathrm{R}$ & $A$ & C & $\mathrm{R}$ & $A$ & C & $\mathrm{R}$ & $A$ & $\mathrm{C}$ & $\mathrm{R}$ & $A$ \\
\hline EXPERT 1 & 5 & 5 & 5 & 6 & 6 & 6 & 5 & 5 & 6 & 5 & 5 & 5 & 6 & 6 & 6 & 6 & 6 & 6 \\
\hline EXPERT 2 & 6 & 6 & 6 & 6 & 6 & 6 & 6 & 6 & 6 & 6 & 6 & 6 & 6 & 6 & 6 & 6 & 6 & 6 \\
\hline EXPERT 3 & 4 & 6 & 6 & 6 & 4 & 4 & 6 & 4 & 4 & 6 & 6 & 6 & 6 & 6 & 6 & 6 & 6 & 3 \\
\hline EXPERT 4 & 4 & 5 & 5 & 6 & 6 & 6 & 6 & 6 & 6 & 6 & 6 & 6 & 6 & 6 & 6 & 6 & 6 & 6 \\
\hline EXPERT 5 & 5 & 6 & 6 & 5 & 1 & 6 & 1 & 5 & 5 & 6 & 6 & 6 & 6 & 6 & 6 & 6 & 6 & 6 \\
\hline EXPERT 6 & 4 & 6 & 6 & 4 & 6 & 6 & 4 & 6 & 6 & 3 & 6 & 6 & 3 & 6 & 6 & 3 & 6 & 6 \\
\hline X CRITERIA & 4.7 & 5.7 & 5.7 & 5.5 & 4.8 & 5.7 & 4.7 & 5.3 & 5.5 & 5.3 & 5.8 & 5.8 & 5.5 & 6.0 & 6.0 & 5.5 & 6.0 & 5.5 \\
\hline X ITEM & & 5.33 & & & 5.33 & & & 5.17 & & & 5.67 & & & 5.83 & & & 5.67 & \\
\hline X COMPETENCE & & & & & 5.28 & & & & & & & & & 5.72 & & & & \\
\hline X VIRTUE & & & & & & & & & 0 & 50 & & & & & & & & \\
\hline
\end{tabular}

With respect to Temperance (Table 4), an average of 5.61 out of 6 is observed. Besides, Personal development and Emotional management competences show high averages of 5.56 and 5.67 respectively. Means of each item (evaluating the criteria of clarity, relevance and appropriateness) are in all cases higher than 5. Once again, clarity criterion show, the lowest mean values, especially in item 2 of Personal development (4.5).

Table 4. Temperance evaluation

\begin{tabular}{|c|c|c|c|c|c|c|c|c|c|c|c|c|c|c|c|c|c|c|}
\hline & \multicolumn{18}{|c|}{ TEMPERANCE } \\
\hline & \multicolumn{9}{|c|}{ PERSONAL DEVELOPMENT } & \multicolumn{9}{|c|}{ EMOTIONAL MANAGEMENT } \\
\hline & \multicolumn{3}{|c|}{ ITEM 1} & \multicolumn{3}{|c|}{ ITEM 2} & \multicolumn{3}{|c|}{ ITEM 3} & \multicolumn{3}{|c|}{ ITEM 1} & \multicolumn{3}{|c|}{ ITEM 2} & \multicolumn{3}{|c|}{ ITEM 3} \\
\hline & $\mathrm{C}$ & $\mathrm{R}$ & A & $\mathrm{C}$ & $\mathrm{R}$ & A & $\mathrm{C}$ & $\mathrm{R}$ & A & C & $\mathrm{R}$ & A & $\mathrm{C}$ & $\mathrm{R}$ & $\mathrm{A}$ & $\mathrm{C}$ & $\mathrm{R}$ & $A$ \\
\hline EXPERT 1 & 6 & 6 & 6 & 6 & 6 & 6 & 5 & 6 & 6 & 4 & 5 & 5 & 5 & 6 & 5 & 5 & 5 & 5 \\
\hline EXPERT 2 & 5 & 6 & 6 & 6 & 6 & 6 & 5 & 6 & 6 & 6 & 6 & 6 & 6 & 6 & 6 & 6 & 6 & 6 \\
\hline EXPERT 3 & 6 & 6 & 6 & 6 & 6 & 4 & 6 & 6 & 4 & 6 & 6 & 6 & 6 & 6 & 6 & 6 & 6 & 6 \\
\hline EXPERT 4 & 6 & 6 & 6 & 4 & 4 & 4 & 6 & 6 & 6 & 6 & 6 & 6 & 6 & 6 & 6 & 6 & 6 & 6 \\
\hline EXPERT 5 & 6 & 6 & 6 & 1 & 6 & 6 & 6 & 6 & 6 & 6 & 6 & 6 & 6 & 6 & 6 & 6 & 6 & 6 \\
\hline
\end{tabular}


IJASOS- International E-Journal of Advances in Social Sciences, Vol. VII, Issue 21, December 2021

\begin{tabular}{|c|c|c|c|c|c|c|c|c|c|c|c|c|c|c|c|c|c|c|}
\hline EXPERT 6 & 4 & 6 & 6 & 4 & 6 & 6 & 4 & 6 & 6 & 3 & 6 & 6 & 3 & 6 & 6 & 3 & 6 & 6 \\
\hline X CRITERIA & 5.5 & 6,0 & 6.0 & 4.5 & 5.7 & 5.3 & 5.3 & 6.0 & 5.7 & \begin{tabular}{|l|l|}
5.2 \\
\end{tabular} & 5.8 & 5.8 & \begin{tabular}{|l|l|}
5.3 \\
\end{tabular} & 6.0 & 5.8 & 5.3 & 5.8 & 5.8 \\
\hline X ITEM & & 5.83 & & & 5.17 & & & 5.67 & & & 5.61 & & & 5.72 & & & 5.67 & \\
\hline X COMPETENCE & \multicolumn{9}{|c|}{5.56} & \multicolumn{9}{|c|}{5.67} \\
\hline X VIRTUE & \multicolumn{18}{|c|}{5.6} \\
\hline
\end{tabular}

Regarding Justice (Table 5), a mean of 5.69 out of 6 is observed, a mean of 5.63 for Leadership and a mean of 5.76 for Teamwork. Averages for each item (assessing the criteria of clarity, relevance and appropriateness) are in all cases higher than 5.

Table 5. Justice evaluation

\begin{tabular}{|c|c|c|c|c|c|c|c|c|c|c|c|c|c|c|c|c|c|c|}
\hline & \multicolumn{18}{|c|}{ JUSTICE } \\
\hline & \multicolumn{9}{|c|}{ LEADERSHIP } & \multicolumn{9}{|c|}{ TEAMWORK } \\
\hline & \multicolumn{3}{|c|}{ ITEM 1} & \multicolumn{3}{|c|}{ ITEM 2} & \multicolumn{3}{|c|}{ ITEM 3} & \multicolumn{3}{|c|}{ ITEM 1} & \multicolumn{3}{|c|}{ ITEM 2} & \multicolumn{3}{|c|}{ ITEM 3} \\
\hline & $C$ & $\mathrm{R}$ & $A$ & $C$ & $\mathrm{R}$ & $A$ & $\mathrm{C}$ & $\mathrm{R}$ & $A$ & $\mathrm{C}$ & $\mathrm{R}$ & $A$ & $C$ & $\mathrm{R}$ & $A$ & $\mathrm{C}$ & $\mathrm{R}$ & $A$ \\
\hline EXPERT 1 & 4 & 5 & 5 & 5 & 5 & 5 & 5 & 6 & 6 & 5 & 6 & 6 & 6 & 5 & 5 & 5 & 6 & 6 \\
\hline EXPERT 2 & 6 & 6 & 6 & 6 & 6 & 6 & 6 & 6 & 6 & 6 & 6 & 6 & 6 & 6 & 6 & 6 & 6 & 6 \\
\hline EXPERT 3 & 6 & 6 & 4 & 6 & 6 & 4 & 6 & 6 & 4 & 6 & 6 & 4 & 6 & 6 & 4 & 6 & 6 & 4 \\
\hline EXPERT 4 & 6 & 6 & 6 & 6 & 6 & 6 & 6 & 6 & 6 & 6 & 6 & 6 & 6 & 6 & 6 & 6 & 6 & 6 \\
\hline EXPERT 5 & 6 & 6 & 6 & 6 & 6 & 6 & 6 & 6 & 6 & 6 & 6 & 6 & 6 & 6 & 6 & 6 & 6 & 6 \\
\hline EXPERT 6 & 4 & 6 & 6 & 4 & 6 & 6 & 4 & 6 & 6 & 5 & 6 & 6 & 5 & 6 & 6 & 5 & 6 & 6 \\
\hline X CRITERIA & 5.3 & 5.8 & 5.5 & 5.5 & 5.8 & 5.5 & 5.5 & 6.0 & 5.7 & 5.7 & 6.0 & 5.7 & 5.8 & 5.8 & 5.5 & 5.7 & 6.0 & 5.7 \\
\hline X ITEM & & 5.56 & & & 5.61 & & & 5.72 & & & 5.78 & & & 5.72 & & & 5.78 & \\
\hline X COMPETENCE & \multicolumn{9}{|c|}{5.63} & \multicolumn{9}{|c|}{5.76} \\
\hline X VIRTUE & \multicolumn{18}{|c|}{5.69} \\
\hline
\end{tabular}

To illustrate the overall perception of the experts, it can be seen (Table 6) that the average ratings of the experts are very positive (between 5.33 and 5.96). Furthermore, experts' scores are quite homogeneous since the Pearson coefficient of variation (CV) takes values lower than 0.30 . In this sense, we can indicate that the mean scores of the experts are representative of the set of responses given by each of them.

Table 6. Evaluation of the global questionnaire by experts

\begin{tabular}{|c|c|c|c|}
\cline { 2 - 4 } \multicolumn{1}{c|}{} & MEAN & SD & CV \\
\hline EXPERT 1 & 5.43 & 0.60 & 0.11 \\
\hline EXPERT 2 & 5.96 & 0.20 & 0.03 \\
\hline EXPERT 3 & 5.43 & 0.90 & 0.17 \\
\hline EXPERT 4 & 5.83 & 0.53 & 0.09 \\
\hline EXPERT 5 & 5.46 & 1.37 & 0.25 \\
\hline EXPERT 6 & 5.33 & 1.11 & 0.21 \\
\hline
\end{tabular}

Finally, to analyse the representativeness of the item means obtained from experts' assessment, the Pearson coefficient of variation was calculated for each item (Table 7). The coefficients do not exceed 0.30 , so that the item means can be considered representative indicators of the data set.

Table 7. Mean, Standard Deviation (SD) and Pearson's Coefficient of Variation (CV) of items

\begin{tabular}{|c|c|c|c|c|}
\hline COMPETENCE & ITEM & MEAN & SD & CV \\
\hline \multirow{3}{*}{ Critical thinking } & Item 1 & 5.17 & 0.94 & 0.18 \\
\cline { 2 - 5 } & Item 2 & 5.22 & 1.14 & 0.22 \\
\cline { 2 - 5 } & Item 3 & 5.39 & 1.03 & 0.19 \\
\hline \multirow{3}{*}{ Decision-making } & Item 1 & 5.83 & 0.41 & 0.07 \\
\cline { 2 - 5 } & Item 2 & 5.61 & 0.55 & 0.10 \\
\cline { 2 - 5 } & Item 3 & 5.72 & 0.68 & 0.12 \\
\hline \multirow{2}{*}{ Resilience } & Item 1 & 5.33 & 0.62 & 0.12 \\
\cline { 2 - 5 } & Item 2 & 5.33 & 1.23 & 0.23 \\
\hline
\end{tabular}




\begin{tabular}{|c|c|c|c|c|}
\hline & Item 3 & 5.17 & 1.21 & 0.23 \\
\hline \multirow{4}{*}{ Proactivity } & Item 1 & 5.67 & 0.68 & 0.12 \\
\cline { 2 - 5 } & Item 2 & 5.83 & 0.41 & 0.07 \\
\cline { 2 - 5 } & Item 3 & 5.67 & 0.82 & 0.14 \\
\hline \multirow{3}{*}{ Personal development } & Item 1 & 5.83 & 0.28 & 0.05 \\
\cline { 2 - 5 } & Item 2 & 5.17 & 1.27 & 0.25 \\
\cline { 2 - 5 } & Item 3 & 5.67 & 0.54 & 0.10 \\
\hline \multirow{3}{*}{ Leadership } & Item 1 & 5.61 & 0.72 & 0.13 \\
\cline { 2 - 5 } & Item 2 & 5.72 & 0.54 & 0.09 \\
\cline { 2 - 5 } & Item 3 & 5.67 & 0.68 & 0.12 \\
\hline & Item 1 & 5.56 & 0.76 & 0.14 \\
\cline { 2 - 5 } & Item 2 & 5.61 & 0.69 & 0.12 \\
\cline { 2 - 5 } Teamwork managemen & Item 3 & 5.72 & 0.55 & 0.10 \\
\hline & Item 1 & 5.78 & 0.44 & 0.08 \\
\cline { 2 - 5 } & Item 2 & 5.72 & 0.55 & 0.10 \\
\cline { 2 - 5 } & Item 3 & 5.78 & 0.44 & 0.08 \\
\hline
\end{tabular}

\subsection{Qualitative results}

Main qualitative results of experts' assessment are the following:

Firstly, they commented that the fact of measuring transversal competences based on virtues implies actions and behaviours (shown through items in the questionnaire) should be referenced to good. In this sense, every item was reviewed to see whether the orientation to good is reflected in the behaviours associated with each competency. Consequently, writing was slightly changed in some cases.

Secondly, experts recommended that no more than one aspect should be measured in the same item. In this sense, items that measured more than one element were modified.

Thirdly, we were told that writing of a few items might incite polarized responses (1 or 6). After some discussion, we concluded that any item was polarized, so all of them could incite graded answers.

Finally, as each competence includes only 3 items, experts commented that this might be insufficient to measure them. In this sense, this questionnaire includes the three most significant behaviours for each competence and the virtue to which it is associated. In addition, we have decided not to include more items to don't exceed 24 items, so we can expect an adequate completion by undergraduates. It has been shown that a high number of items may cause fatigue and reduce concentration on the questionnaire and, consequently, truthfulness in the answers.

\section{DISCUSSION}

Numerous articles show the importance of integral formation at university (Briones \& Lara, 2016; Escámez et al., 2008; Esteban \& Buxarrais, 2004; Jover et al., 2011). However, given the complexity of this construct, there is still, a notable lack of a concrete definition of integral formation. Moreover, there are not enough instruments to contribute to a reliable and valid measurement (Curren \& Kotzee, 2014; Morgan et al., 2017).

This research aims to approach to this need by developing a questionnaire of transversal personal competences based on the four cardinal virtues: prudence, fortitude, temperance and justice, which contributes to the measurement of the degree of development of moral formation, a very substantial part of the integral formation of undergraduates.

For the design, the range of each virtue was studied in to determine the two competences that would fit best. The result was a 24-item questionnaire, based on four dimensions (cardinal virtues) and eight competences (critical thinking, decision-making, resilience, proactivity, personal development, emotional management, leadership, and teamwork).

In order to obtain initial evidence of content validity, the questionnaire was submitted to an evaluation committee of 6 experts in competences, virtues and integral formation. Results showed very positive evaluations of the questionnaire, both as a whole (5.57 out of 6) and in the different virtues and associated competences (in all cases means above 5.25 out of). Experts also gave us qualitative feedback which constituted, together with some item scores the main evidence of the small modifications for the improvement of the final questionnaire (Table 1). 
It can be concluded that this study presents a questionnaire, the CVQ (Competences and Virtues Questionnaire), relevant to measure the self-perception about the development of some competences associated with the cardinal virtues that can contribute to the integral formation of undergraduates. In this line, considering the importance given to integral formation at university since its origins, and given that, until our knowledge, there are no questionnaires designed to measure it in the university context, the CVQ can bring light to undergraduates, professors, and employers, especially if the trajectory of the student can be drawn from the beginning to the end of their university stage. Moreover, it would make possible to reformulate or reinforce, if necessary, some of the contents of integral formation at university.

As future lines, a study of the questionnaire's reliability, homogeneity, and construct validity will be carried out.

\section{REFERENCE LIST}

Aristóteles (1985) Ética Nicomáquea. Ética Eudemia. Madrid: Gredos.

Briones, E., \& Lara, L. (2016). Educación ética en la Universidad a través del diálogo multicultural online. Comunicar, 14(47), 99-107. https://doi.org/10.3916/C47-2016-10

Covey, S. R. (2009). Los 7 hábitos de la gente altamente efectiva. Barcelona. España: Paidós. Paidós.

Crespí, P. (2019). La necesidad de una formación en competencias personales transversales en la universidad. Diseño y evaluación de un programa de formación. Fundación Universitaria Española.

Crespí, P. \& García-Ramos, J.M. (2021). Competencias genéricas en la universidad. Evaluación de un programa formativo. Educación XX1, 24(1), 297-327, https://doi.org/10.5944/educXX1.26846

Crespí, P., \& García-Ramos, J. M. (2021). Competencias genéricas en la universidad. Evaluación de un programa formativo Educación XX1, 24(1), 297-327. https://doi.org/10.5944/educxx1.26846

Curren, R., \& Kotzee, B. (2014) 'Can virtue be measured?'. Theory and Research in Education, 12(3): 266283.

Domínguez Prieto, X. M. (2011). Psicología de la persona. Fundamentos antropológicos de la psicología y la psicoterapia. Ediciones Palabra.

Escobar, J., \& Cuervo, A. (2008). Validez de contenido y juicio de expertos: una aproximación a su utilización. Avances en Medición, 6, 27-36.

Escámez, J., García-López, R., \& Jover, G. (2008). Restructuring University Degree Programmes: A New Opportunity for Ethics Education? Journal of Moral Education, 37(1), 41-53. https://doi.org/10.1080/03057240701803676

Esteban, F., \& Buxarrais, M. R. (2004). El aprendizaje ético y la formación universitaria más allá de la causalidad. Teoría de la educación, 16, 91-108.

Esteban, F., \& Román, B. (2016). ¿Quo vadis, universidad? Editorial UOC.

Frankl, V. E. (1979). El hombre en busca de sentido. Herder.

García Hoz, V. (1970). Principios de pedagogía sistemática. Ediciones RIALP.

García Hoz, V. (1997). Glosario de educación personalizada. Índices/García Hoz (Coord.). Ediciones RIALP.

García-Ramos, J. M. (1986). Validación de constructo en el ámbito pedagógico. 174, 535-554.

García-Ramos, J. M. (2017). Misión de la Universidad en los Tiempos de la Postverdad Ávila.

García-Ramos, J. M. (1991). La formación integral: objetivo de la Universidad. Algunas reflexiones sobre la educación en la Universidad. Revista Complutense de Educación, 2(2), 323-335.

Goleman, D. (1995). Emotional intelligence. Bantam Books.

González, J. \& Wagenaar, R. (2008). Universities' contribution to the Bologna Process. An Introduction. Bilbao: Publicaciones de la Universidad de Deusto.Grotberg, E. H. (1995). The International Resilience Project: Promoting Resilience in Children.

Jover, G., López, E., \& Quiroga, P. (2011). La universidad como espacio cívico: valoración estudiantil de las 
modalidades de participación política universitaria. Revista de Educación, número extraordinario, 6991.

Manual del Formador HCP. (2018). Vicerrectorado de Formación Integral de la Universidad Francisco de Vitoria.

Morgan, B., Gulliford, L., \& Kristjánsson, K. (2017). A new approach to measuring moral virtues: the multicomponent gratitude measure. Personality and Individual Differences 107, 179-189. doi: 10.1016/j.paid.2016.11.044

Muñoz, C., Crespí, P., \& Angrehs, R. (2011). Habilidades sociales. Ediciones Paraninfo.

Pérez-Díaz, V. (2010). Universidad, ciudadanos y nómadas. Ediciones Nobel.

Pieper, J. (2017). Las virtudes fundamentales. Ediciones RIALP.

Riggio, R.E., \& Zhu, W., Reina, C., \& Maroosis, J. (2010). Virtue-based measurement of ethical leadership: The Leadership Virtues Questionnaire. Consulting Psychology Journal: Practice and Research. 62 (4). 235-250. https://doi.org/10.1037/a0022286.

Salovey, P., \& Mayer, J. D. (1990). Emotional intelligence. Imagination, Cognition and Personality, 9, 185211.

Trigo, T. (2010). Las virtudes humanas. Curso sobre las virtudes: La perfección de la persona (2 de 7): Las virtudes humanas.

Vanistendael, S. (2003). La resiliencia en lo cotidiano. In M. Manciaux (Ed.), La resiliencia: resistir y rehacerse. Gedisa. 